\title{
СУСПIПЫНО-ГЕОГРАФТ/ИII 口OCAIOXEHHЯ
}

\author{
УДК 911.3:30 \\ doi: $10.15407 / \mathrm{ugz} 2015.04 .024$ \\ І. В. Гукалова \\ Інститут географої Національної академії наук України, Київ

\section{ПРОСТОРОВА ІДЕНТИЧНІСТЬ НАСЕЛЕННЯ В РУСЛІ НОВИХ НАПРЯМІВ ДОСЛІДЖЕННЯ У СУСПІЛЬНІЙ ГЕОГРАФІЇ}

Мета публікації-розкриття змісту терміну «просторова ідентичність населення» зхарактеристикою основнихії складових в контексті зміни уявлень про простір (територію). У статті розглянуто суть поняття ідентичності та обґрунтовано необхідність визначення її не як особистісного, а як колективного атрибута, притаманного соціально-територіальній спільноті. Новизна роботи полягає в обґрунтуванні необхідності розширення предметного поля суспільної географії за рахунок дослідження зрізів ментального зв'язку населення з територією, критичного осмислення і вдосконалення понять і підходів, які є фрундаментом цього. Наведено авторське визначення просторової ідентичності населення, а також сформульовані нові напрями досліджень, опрацювання яких сприятиме розумінню механізмів її актуалізації.

Ключові слова: простір; територія; сприйняття простору; просторова ідентичність; територіальна спільнота; регіональний соціум.

\section{V. Gukalova}

Institute of Geography of the National Academy of Sciences of Ukraine, Kyiv SPATIAL IDENTITY OF POPULATION IN THE MAINSTREAM NEW LINES OF RESEARCH IN HUMAN GEOGRAPHY

The purpose of the publication - disclosure of the «spatial population identity" term with the characteristics of its main components in the context of changing perceptions of space (territory). The essence of identity concept and necessity to defy it not as personal but as a collective inherent attribute of socio-territorial community is reviewed in the article.

The novelty of the work lies in the rationale for extension of social geography subject field through the study of the mental sections of the population connection to the territory, critical thinking as well as improvement of the concepts and approaches which underpin it. Author's definition of the population spatial identity has been presented as well as the new areas of research, study of which will contribute to understanding the mechanisms of its actualization have been formulated.

Key words: space; territory; perception of space; spatial identity; territorial community; regional society.

Актуальність теми дослідження

У 1990-х рр. у зарубіжній географії з’явився потужний дослідницький напрям, прихильники якого активно демонстрували свій інтерес до проблем, рівнів, особливостей формування територіальної ідентичності. Його поява була зумовлена тим, що в умовах глобалізації національні держави, як цементуючі суспільство територіальні політичні спільності, почали втрачати свої домінуючі позиції на фоні зростання значення наднаціональних інтеграційних утворень. Підвищувалася роль окремих регіонів і міст, їх транскордонної активності при посиленні значення регіональних і локальних факторів формування такого успіху.

Паралельно зі змінами у самому суспільстві, соціальній структурі пріоритетною стала і проблема сприйняття території, оскільки у процесі життєдіяльності населення та цілеспрямованої самопрезентації територія набуває характеристик, які згодом стають їі стійкими властивостями у свідомості людей. Дедалі частіше йдеться про бренд території як ментальний конструкт, що поєднує в собі образи, емоційні оцінки, враження та сподівання щодо конкретної місцевості.

Сталий і надійний бренд країни (регіону, міста), як і добре ім'я людини (незалежно від об'єктивних обставин), завжди створюють кращі умови їх функціонування та розвитку.

У проблематиці ментального значення простору в житті людей в Україні на перших позиціях досліджень останніми роками знаходяться проблеми формування національної ідентичності. Це зумовлено становленням державності, а також пострадянською кризою ідентичності, пов'язаною iз втратою старих символів колективної ідентифікації та невизначеністю нових, які могли б слугувати надійними орієнтирами соціальної поведінки.

Процес формування єдиного гуманітарного простору в Україні ніколи не був простим, супроводжувався демонтажем старої тоталітарної системи, трансформаційними процесами в економіці та способі життя людей, інтенсивним впливом «зовнішнього середовища», що менш за все сприяло суспільній згуртованості. Через чверть століття після здобуття незалежності «оголилися» дві паралельні «реальності» - проукраїнська та антиукраїнська, що разом із зовнішньою агресією призвело до анексії Криму і військового протистояння на Сході України. Тому осмислення всіх чинників формування національної ідентичності 
набуває особливої актуальності у міждисциплінарних дослідженнях.

Але національна ідентичність - це тільки один iз зрізів, що виражає зв'язаність людей як із територією, так і з локальним соціумом. Послідовне співвіднесення людей зі своїм населеним пунктом, регіоном, нацією чи державою демонструють неоднозначність і складність процесів просторової ідентифікації й стимулюють дослідження з цієї тематики.

\section{Стан вивченості питання}

У науковій літературі поняття «ідентичність», за частотою вживання, починає випереджати такі поняття як самосвідомість, менталітет та інші. При цьому тлумачення самого поняття ідентичності $\epsilon$ дуже різними. У 1960-х рр. німецькі соціологи П. Бергер і Т. Лукман у своїй теорії «соціального конструювання реальності» відзначали, що «ідентичність залишається незрозумілою, доки вона не має місця в світі» [3, с. 280]. Дійсно, осмислення колективної соціальної ідентичності здійснюється у конкретному місці й часі, ще й у проекції впливу iii на соціально-економічне життя населення.

Вихідні положення концепту просторової ідентичності були розроблені в межах соціології простору, соціальної психології та філософії ще у 197080 -х рр., хоча значний внесок здійснили і географи, в основному зарубіжні.

Грунтовні оцінки різних видів ідентичності знаходимо у працях Б. Андерсона, Е. Гідденса, М. Кастельса, Ф. Тьонніса, 3. Фрейда, С. Хантінгтона, Я. Щепанського, Е. Еріксона, серед географів слід виділити роботи Е. Соджі, А. Лефевра, Д. Хайден, в яких розкрито значення території та місця як носіїв соціальної й культурної пам'яті.

Значний внесок у розуміння ідентичності зробили сучасні українські географи О. Шаблій, І. Ровенчак, А. Мельничук, а також російські-О. Вендіна, Д. Візгалов, Д. Замятін, Н. Замятіна, В. Колосов, Л. Смірнягін, О. Ткаченко, О. Карлова та інші.

В Українському географічному журналі була опублікована стаття Я. Олійника i О. Гнатюка «Методичні підходи до дослідження територіальної ідентичності», де автори представили інтегральну класифікацію підходів до вивчення цього ментально-географічного феномену, що стало однією із перших спроб українських науковців узагальнити i систематизувати шляхи ії осмислення [10], а також стаття Г. Підгрушного і К. Мезенцева «Привабливість території для проживання людини: методологічні та прикладні аспекти дослідження», в якій науковці на прикладі конкретного дослідження міст розглянули географічні образи територій як чинник ідентифікації населення [12].

М е т а цієї публікації - обгрунтування сутності терміну «ідентичність», а також основних напрямів дослідження, виходячи з актуальних проблем роз- витку українського суспільства і потреб розширення предмету й оновлення методологічного інструментарію суспільної географії. У західних країнах цій проблематиці відповідають навіть назви самої науки - Anthropogeographie, human geography, la geographie humaine. У вітчизняних наукових координатах проблему просторової ідентичності опрацьовують на межі соціальної, політичної географії і географії культури.

\section{Виклад основного матеріалу}

Місце, територія, простір відносяться до тих вимірів людського життя, які є самоочевидними і не піддаються сумніву. Але вони завжди були дуже значимими, забезпечували стабільність і передбачуваність життя людей. Між людиною і місцем іiі локалізації - проживання, праці, відпочинку, спілкування тощо - існує вкрай важливий, але недостатньо вивчений зв'язок. Немає сумніву у тому, що не тільки людина впливає на своє фізичне оточення шляхом його перетворення, але й навколишнє середовище накладає свій відбиток на світосприйняття і поведінку людей (міграційну, електоральну тощо).

На сучасному етапі розвитку у суспільній географії відбуваються значні методологічні зрушення, внаслідок яких формується розуміння іiї базової категорії «простір» як соціально-географічного продукту (конструкту) - результату економічного і культурного виробництва $і$ субб'єктивного сприйняття. У свою чергу, ці зрушення зумовлюють широке запозичення знань і методичного інструментарію інших наук - соціології, культурології, поведінкової географії (behavioral geography) тощо. Через так зване «присвоєння» простору осмислюються найважливіші теоретичні проблеми науки - автентичності і репрезентації процесів, які відбуваються чи відбувалися на території, механізмів і факторів утворення «образів» міст і регіонів. Не менш цікавим $є$ аналіз того, чиї інтереси, системи репрезентації, чия пам'ять і культурний спадок втілені в окремих місцях простору (міста, регіону) і наскільки це впливає на якість життя населення.

Методологічні традиції соціально-економічної географії за радянських часів будувалися на дослідженнях техніко-економічного спрямування, сформульованих провідними географами закономірностях організації господарства і населення, розміщення населених пунктів як компонентів, які позбавлені самосвідомості. Нині помітним стає перехід до досліджень суспільства як сукупності індивідів $з$ їх духовною сферою життя, динамічним уявленням про світ, своє місце у ньому, з їх свободою (чи несвободою) вибору.

Одним 3 перших на кардинальній зміні підходів до простору наголосив швейцарський географ Б. Верлен, який вважає географію не наукою про простір, а наукою про «дії у просторі». За його словами, «дії ...завжди являють собою вираз певних 
заздалегідь заданих соціальних, економічних та природних умов, в яких вони здійснюються» [5]. На його думку, суспільна (головним чином, соціальна) географія ще тільки має виробити правила аналізу артефактів, які дозволяють розрізняти одночасну локалізацію їх у фізичному (матеріальні об'єкти) і соціальному (смислові змісти) світах [4]. Сам простір тоді має визначатися не тільки як фізичне поле соціальної взаємодії, а й як конструкт у свідомості населення із багатомірною характеристикою простору як місця 3 тією чи іншою прив'язкою населення до нього. Традиційне для географа «освоєння простору» перетворюється на смислове його «присвоєння» - на цьому зламі й формується зміст просторової ідентичності.

Тлумачні словники визначають поняття «освоїти» як оволодіти чим-небудь, навчитися щось споживати, користуватися, зрозуміти, запам'ятати, а «присвоїти» означає «самовільно зробити своїм» ${ }^{1}$. Про освоєність території дізнаються, судячи 3 присутності на ній людей, виробничої активності, інфраструктури; з того, чи обирають іiі місцем зустрічей, інвестицій і загалом - життя; чи легко iii впізнати; чи властивий їй індивідуальний смисл, який відрізняє іï від інших територій; а про присвоєння території можна казати судячи по тому, чи проживає тут населення, яке асоиіює себе з даною територією.

Сучасне суспільство переходить від виробництва речей у просторі до творення простору як такого. Невипадково планування сучасної економіки перетворюється на геопросторове планування 3 усіма його напрямами, включаючи і ландшафтне планування, що наразі починає впроваджуватися i в Україні [8]. Ця практика є затребуваною у розвинених європейських країнах, де територію розглядають як рушійну силу у відтворенні культури, мови, звичаїв і населення. Там територію віддавна сприймають як основу ідентичності, і соціум на різних рівнях ієрархії - від окремого містечка до Єврорегіонів - постійно постачає досвід, факти, символи, а також конкретні проекти для колективної солідарності.

Історичний досвід США свідчить, що розвиненість почуття місця, тобто здатності громадян ідентифікувати себе у просторі не тільки країни чи частини адміністративно-територіального устрою, але також і невеликого міста, ферми, мікрорайону, і розвиненість низової демократії взаємозумовлені. Причому місце - це не тільки «мала батьківщина», скоріше це суспільний осередок, належність до якого означає для людини не менше, ніж рідний регіон або країна загалом. Таке почуття в американців пов'язано $з$ історичним освоєнням території, точніше, з двома періодами американської історії - заселенням Нової Англії маленькими громадами,

${ }^{1}$ Словник української мови: в 11 томах. Он-лайн версія. Том 5, 1974. - C.757. http://sum.in.ua/s/osvojuvaty що заклали фундамент американської низової демократії, і освоєнням фронтиру ${ }^{2}$, який сформував «нову людину - американця», за природою своєю локала-індивідуаліста, здатного відповідати за свою землю [11].

Про присвоєний простір багато писав П'єр Бурд’є. Одне 3 його висловлювань є дуже актуальним: «Присвоєний простір є одним 3 місць, де влада затверджується і здійснюється у самій своїй хитромудрій формі як символічне або непомітне насилля...» [2]. Інший французький соціолог та філософ А. Лефевр розмірковував над формулюванням теорії, здатної об'єднати різнорівневі площини дослідження простору: 1) фізичну, де увага має зосереджуватися на природі й космосі; 2) ментальну, де йтиметься про логічні узагальнення (метафізичні репрезентації простору); 3) суспільну - як площину соціальної практики [9]. Простір, у сенсі присвоєння або приналежності, стає символічним, соціальним і навіть сентиментальним продуктом [17].

Як відомо, виділення об'єктивної й суб'єктивної реальності, одна 3 яких охоплює матеріальні речі, їх властивості і відносини, процеси, що не залежать від свідомості людини та ії уявлень про них, а інша, навпаки, є виключно реальністю ідей, уявлень і смислів, завжди означало необхідність інтегративного підходу до оцінок розвитку суспільства та якості його життя 3 позицій об'єктивізму та суб'єктивізму. Аналізу об'єктивної реальності завжди більше відповідав географічний детермінізм і посибілізм, оцінці суб'єктивної реальності - соціальний детермінізм і посибілізм. Концепт просторової ідентичності будується на їх об'єднанні.

У науковий обіг поняття ідентичності ввів 3. Фрейд. Він мав на увазі «подвійний» феномен - біологічну і соціальну адаптацію людини до навколишнього середовища і вважав обидві сторони процесу однаково важливими [14].

Термін «просторова ідентичність» (place identity) з'явився значно пізніше - наприкінці 1970-х рр. Американський психолог Г. Прошанський визначав просторову ідентичність як інкорпорацію індивідом місця, території у широку концепцію власного «я», як попурі спогадів, інтерпретацій, ідей i почуттів по відношенню до фізичного простору, певних місць і типів місць [18].

У суспільній (зокрема соціальній) географії поняття просторової ідентичності тісно пов'язане 3 поняттям територіальна спільність людей (регіональний, локальний соціум, місцева громада

\footnotetext{
2 Фронтир (від англ. frontier — «кордон», «порубіжжя») - зона освоєння Дикого Заходу на межі зіткнення цивілізації 3 корінним населенням 3 несформованим суспільством, який згодом поступово пересувався на Захід Північної Америки. Життя і боротьба у цій зоні й сформували американську націю (суспільство) як «а composite nationality».
} 


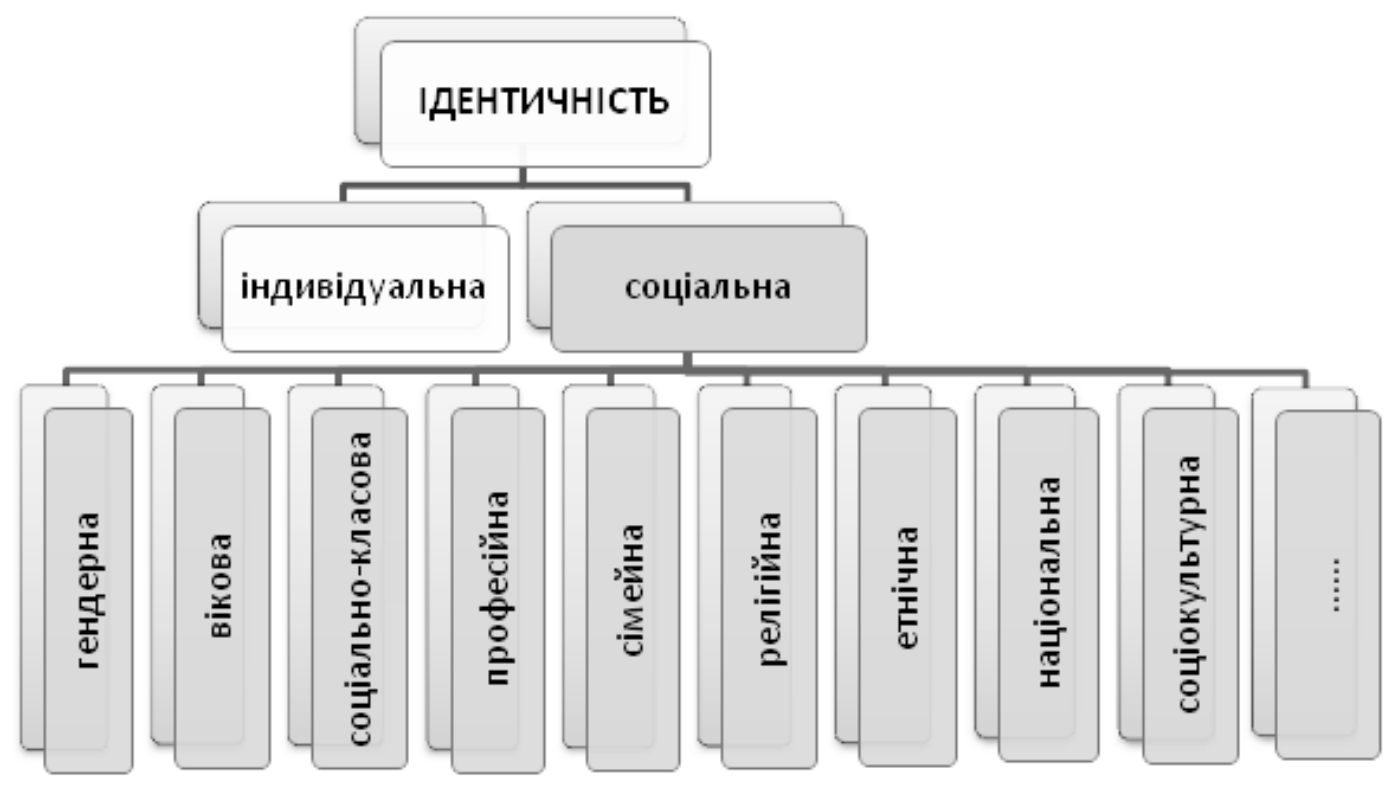

Рисунок 1. Компоненти (зрізи) соціальної самоідентифікації населення

та ін.), що являють собою спільноти, члени яких пов’язані узами загальних відносин до території, на якій вони проживають, і тих відносин, які витікають 3 факту проживання на спільній теритоpiï $[15$, с.160]. Тривалий час, 3 різних причин, поняття територіальної спільності спиралося на адміністративно-територіальний устрій території, отже будь-яка адміністративна одиниця розглядалася одночасно і як простір життєдіяльності населення, що закріплювався й у свідомості.

Наразі науковий дискурс зміщується у площину вивчення територіальної спільності людей як спільності «за самовизначенням» - зі специфічними, притаманними тільки їй характеристиками регіональної самосвідомості, системи цінностей, норм і правил поведінки, територіальних інтересів і просторової перцепції [7]. 3 тими чи іншими місцями асоціюються й ті чи інші спільноти, через які визначаються ці місця і які самі визначаються через свою належність до цих місць. Ці території й пов’ язані з ними спільноти характеризуються різними масштабами і рівнями інституціоналізації, проте всі вони відіграють роль у самоідентифікації людей, у наповненні їх життя сенсом, значенням i цілями.

Серед різновидів ідентичності важливі два: індивідуальна i соціальна. Не зупиняючись на властивостях, здібностях особи - тих характеристиках конкретної людини, які роблять іiі унікальною серед інших, звернемо увагу на процес ідентифікації людини $з$ певним соціальним середовищем - т.зв. соціальну ідентифікацію. Вона має багато «зрізів», у межах яких відбувається усвідомлення, оцінювання своєї належності до тих чи інших спільнот на тій чи іншій території (рис.1).
У межах відповідних зрізів людина відчуває свою роль і значення як жінки чи чоловіка, представника молоді, середнього або старшого покоління, 3 притаманними їм нормами поведінки, усвідомлює свою єдність 3 певними професійними групами чи конкретною діяльністю, ідентифікує себе зі зразками сімейних ролей - чоловіка і дружини, батька чи матері, сина чи доньки, чи є вірянином - членом певної конфесії, усвідомлює себе членом етнічної спільноти, або громадянином держави, тобто ототожнює себе 3 культурними нормами, системними цінностями того соціокультурного середовища, в якому перебуває. За своєю суттю це - зрізи соціально-просторової ідентифікації, тому що кожен з означених аспектів проявляється унікальними чином, відповідно до особливостей простору і часу. Вони взаємодіють один з одним i створюють надскладну синергетичну цілісність, яку можна розглядати як силу, здатну об'єднати людей, мотивувати їх на досягнення соціально значимих цілей, сприяти розвитку і суспільства, i держави, і конкретного регіону.

Отже, просторова ідентичність - ие пережиті чи усвідомлені смисли суб' сктивної суспільногеографічної реальності, які формують відчуття приналежності людини до певного простору $i$ соціуму. Вона не є сукупністю індивідуальних ментальних вражень, а усвідомленням, опосередкованим соціально-економічними, культурними і політичними чинниками [6]. До таких чинників слід віднести особливості розвитку соціальної сфери та інфраструктури, рівень соціальної безпеки, соціально-культурне середовище, пріоритетні морально-етичні норми, сформовані у певному соціумі погляди на світ і на конкретну територію, мас- 
медійну діяльність та інше.

За Б. Андерсоном, просторова ідентичність - це сприйняття індивідом себе як представника «уявної спільноти», що грунтується на єдності території проживання, історії та традицій, соціокультурного досвіду, ціннісних орієнтацій і способу життя [1].

Люди різного статусу і соціальної приналежності, окремі регіони завжди будуть виділятися як специфічні. Існує такий термін: «вернакулярний район», який $\epsilon$ продуктом просторового сприйняття «середньої людини» і являє собою єдність реального географічного простору і суб'єктивного образу як результату сприйняття та інтерпретації цього простору людьми. Знання зафіксованих відповідним способом «масових» стереотипів має не лише пізнавальне, а й практичне значення: воно пов'язане з передбаченням міграційної, торговельної, туристичної та інших форм просторової поведінки населення. Сприйняття людьми навколишньої дійсності стає базою їх самосвідомості - уявлення про неї, а не сама дійсність.

Як географічний феномен, просторова ідентичність проявляється на різних рівнях і стосується об'єктів різного масштабу та змісту. Можна виділити глобальний, континентальний, національний, регіональний і локальний рівні ідентичності, на кожному з яких відбувається процес «присвоєння» i сприйняття простору. У зарубіжних публікаціях $\epsilon$ такі усталені означення просторової ідентичності: ідентичність 3 місцем (place identity) (local identity), регіональна ідентичність (regional identity), ідентичність 3 середовищем (environmental identity), міська (urban related identity), ідентичність 3 місцем проживання (settlement identity).

Історично, на етапі об'єднання людей у рід, плем'я, зв'язок між ними, а також з територією їх проживання був дуже тісний і продуктивний. Люди жили спільністю інтересів і потреб, вони були знайомі один 3 одним, формували природну єдність. Просторова ідентичність була усвідомленою і первинною, розуміння інших видів ідентичності прийшло пізніше - у процесі розвитку суспільства, форм зайнятості і професій, формування етносів, історії становлення національних держав, формування громадської відповідальності і т.п.

Маленьке поселення (село, хутір, мале місто) і досі можуть мати ознаки цілісної територіальної спільноти. Однак домінуючими нині є зовсім інші поселення - великі, де панує не стільки спільнота, громада (Gemeinschaft), скільки суспільство загалом (Gesellschaft), а зв'язки між людьми мають «механічний характер» [13].

Фізична присутність і спільне місце проживання перестають бути підставою для суспільної (громадської) згуртованості, натомість підтримка відносин на великій відстані (яка іноді сягає планетарних величин) стає звичайною справою. Люди зближуються із членами певної соціальної групи скоріше, ніж з тими, хто знаходиться поруч (ефект «соціальних мереж»), але така дійсність породжує негативні наслідки - це і певна соціальна відчуженість, зайва раціональність, агресивність, яка фрагментує суспільство і значно віддаляє його від простору, який колись був якщо не єдиним, то дуже важливим джерелом його життєвих сил. Відповідно, і самі люди дедалі менше очікувань пов'язують із територією. При цьому ознаки відтворення колективної ідентичності можна помітити на всіх рівнях територіальної ієрархії. Здійснюється це через уявлення людей про їх причетність до певного культурного, спортивного, оздоровчого, соціального та будь-якого іншого територіального проекту, який стає засобом підтримки духовної і громадянської єдності [16].

Просторова ідентичність, іiі характеристики пов'язані як $з$ територією, так і з факторами, не пов'язаними 3 територіальним виміром. Можна виділити декілька чітких передумов формування ідентичності, пов'язаних із способом і характером взаємодії людей з територією: географічне положення і розмір території, щільність населення, природа і природно-кліматичні умови, особливості та досвід історичного освоєння території, сприйняття території як базової цінності тощо.

Наприклад, віддаленість, відірваність, периферійне положення можуть інтерпретуватися і як певні соціально-територіальні дефіцити, і як цивілізаційний розрив, а також як віддаленість від центральної влади та її впливів.

Пріоритетна актуальність взаємопов'язаного розгляду проблем територіальної ідентифікації та міграції зумовлена тим, що без руху немає досвіду місия як такого. Щоб краще усвідомити простір свого життя, люди мають побачити його ззовні. Саме досвід переміщень, мандрівок, трудових поїздок (міграція) є значимим у формуванні спочатку об'єктивних уявлень про місце свого життя. Отже, міграцію слід розглядати не тільки як процес механічного руху населення, а й як процес переміщення людей у «зрізах» ідентичностей (професійної, мовної, культурної, етнічної тощо).

Зокрема, слабкість інтеграційних процесів всередині і ззовні країни, а також низький рівень життя населення стали результатом того, що з України щороку виїжджають за кордон лише близько 5\% iii мешканців. Разом з тим, обсяги міждержавних міграцій у загальному обсязі зареєстрованих переміщень в Україні зростають: якщо у 2009 р. на зовнішні міграції припадало 4,1 \% валової міграції, то у 2014 р. вже 6\%을. Водночас, згідно 3 даними Eurostat, щорічно за кордоном бувають $76 \%$ бельгійців, 53\% голландців, 40\% словаків,

${ }^{3}$ Статистичний щорічник за 2014 рік / За ред.І.М.Жук. - Держслужба статистики України. - К., 2015. - 586 с. 
$33 \%$ німців ${ }^{4}$. Розподіл мігрантів за потоками свідчить про те, що в Україні в останне десятиріччя домінували внутрішньообласні переміщення людей (понад 50\% їх загального обсягу). Домінуючим типом міграційного руху був перерозподіл населення між сільською місцевістю та містами у межах одного регіону.

Щодо зовнішньої трудової міграції, яка в Україні щороку зростає, то лідерами тут багато років поспіль $є$ представники західних областей, причому їх поїздки диверсифіковані за різними країнами світу; жителі східних областей у своїх трудових поїздках традиційно були зорієнтовані в основному на Російську Федерацію ${ }^{5}$.

Все це в останні роки вплинуло на формування територіальної ідентичності населення, стереотипи і уявлення про регіони і окремі міста та загальне сприйняття дійсності. Більше цього, зростання міжрегіональних міграційних потоків внаслідок анексії АР Крим Російською Федерацією і військових дій на Сході країни вимушено змінюють ситуацію різновекторності просторової ідентифікації.

\section{Висновки і перспективи подальших досліджень}

Географи давно сприйняли символічний зміст простору, намагаючись локалізувати у фізичному просторі символічні об'єкти, тому стало можливим виділити хорографрію - опис простору у фізичному сенсі і хорологію - осмислення людських дій у певному просторі. Проблематика соціальної дії та формування якості життя населення у конкретних просторових умовах актуалізувала і категорію «просторова ідентичність». Наявність різних підходів дозволяє розглядати процес іiї формування 3 позицій не тільки географії, а й соціології та інших наук, підтверджуючи міждисциплінарний образ цього феномену.

Значення просторової ідентичності дуже високе, але, як свідчать останні події в нашій державі, мобілізація регіональної самосвідомості може використовуватися в різних інтересах. $€$ загроза того, що в умовах відсутності ідей, які консолідують суспільство загалом, актуалізація форм ідентичностей, сфокусованих на конкретній території, може супроводжуватися розмиванням ідентифікації 3 «великим» суспільством, нацією загалом або цивілізаційними нормами. Водночас, тільки самовизначення людей $з$ простором (територією) спонукає до їх боротьби за право визначати кордони цих територій. Саме тому консолідація просторової ідентичності так важлива.

\footnotetext{
${ }^{4}$ Офіційний сайт Свростату. http://ec.europa.eu/eurostat/ web/population-demography-migration-projections/ migration-and-citizenship-data

${ }^{5}$ Прибиткова I. Сучасні міграційні процеси в Україні // Сайт «Європа без бар'єрів». http://novisa.org.ua/ sychasni-migraciini-procesi-v-ykraini/
}

Здобуття просторової ідентичності потребує звернення до стратегій її конструювання. Тут $є$ два можливих напрями, які відрізняються тим, які саме смисли приписують тим чи іншим територіям:

- стратегія пошуку автентичності, яка спирається на минуле,

- створення нових брендів, міфів, значень 3 опорою на існуючі ресурси та історію освоєння території.

В обох випадках йдеться не стільки про пошук «знакових» об'єктів тієї чи іншої території (iconic architecture), а місць, які мають власну історію (original places) чи мають намір «творити» iï сьогодні. Ці місця об'єднують три складові: 1) географічні об'єкти, 2) соціальні практики, сформовані навколо них, і 3) культурне середовище, що формується навколо соціуму, здійснюючого ці практики. Ця триєдина єдність чекає на своїх дослідників.

Наразі виділимо основні, на наш погляд, проблемні напрями суспільної географії, опрацювання яких сприятиме розумінню механізмів актуалізації просторової (територіальної) ідентичності.

- Аналіз міграиійних прочесів. Мотивація мігрантів при прийнятті рішень про переїзд, специфіка їх адаптації, а також взаємовідносини 3 корінним населенням, включаючи стереотипи про території колишнього проживання - ці складові безпосередньо пов'язані 3 вираженістю різних зрізів ідентичності, почуттям комфорту і захищеності населення. Інтенсифікація міграційних рухів між країнами і всередині країн (у т.ч. вимушена міграція) вказує на актуальність пізнання латентних причин цього процесу.

- Територіальний маркетинг $і$ брендинг териmopiï, які тісно прив'язані до розвитку громадянського суспільства та місцевого самоврядування. Створення іміджевих характеристик завжди впливало на залучення інвестицій, конкурентоспроможність, на ринок праці й нерухомості, а також на суб'єктивну оцінку населенням умов життя.

- Дослідження соиіального капіталу, насамперед оцінка соціальної безпеки людей і довіри до певного географічного простору, рівня згуртованості територіальної спільноти. Постійне спостереження за цими феноменами необхідне через те, що культурне і соціальне середовище (якість життя населення, щільність соціальних контактів) зазнають істотних змін.

- Переосмислення ролі кордонів і транскордонної діяльності, спечифіки прикордонних соиіумів, усіх вимірів «життя на кордоні». Через феномен граничності сприймаються простір і час, цивілізаційні та інші розломи, явища маргіналізації, злочинності, культурних дислокацій.

- Дослідження у сфері геоконфліктологї: територіальна ідентичність може бути платформою для активних громадянських дій, протестів, конф- 
ліктів, що призводить до трансформації соціальноекономічного розвитку регіонів і країн та нового формулювання стратегій їх розвитку.

- Опраиювання проблем реорганізації адміністративно-територіального устрою, деиентралізації й формування механізмів солідарної відповідальності. Вдосконалення територіального устрою передбачає не тільки оптимізацію функцій адмі- ністративного управління, а, насамперед, і самостійне налагодження населенням свого життя, саморегулювання і самоуправління у рамках поселень.

3 цих позицій будь-яка територіальна одиниця перестає бути лише адміністративною, а має розглядатися під кутом соціальної, поселенської структур і ментальної сформованості, тобто у контексті підконтрольних соціуму територій.

\section{References [Jimepamypa]}

1. Anderson, B. (2001). Imagined Communities. Speculation on the origin and spread of nationalism. Kyiv. [in Ukrainian].

[Андерсон Б. Уявлені спільноти. Міркування щодо походження й поширення націоналізму. - К., 2001. - 272 с.]

2. Bourdieu, P. (2005). The physical and social space: the penetration and appropriation. Sociology of social space. SPb.: Aletheia; Moscow: Institute of the experiment. sociology. [in Russian].

[Бурдье П. Физическое и социальное пространства: проникновение и присвоение // Социология социального пространства. - СПб. : Алетейя ; М. : Ин-т эксперимент. социологии, 2005. - 288 с.]

3. Berger, P., Lukman, T. (1995). Social Construction of Reality. A treatise on the sociology of knowledge. Moscow: Medium. [in Russian]. [Бергер П., Лукман Т. Социальное конструирование реальности. Трактат по социологии знания. - М.: Медиум, 1995. -323 с.]

4. Verlaine, B. (1993). Society, action and space. Alternatively, human geography. London and New York. [in Russian].

[Верлен Б. Общество, действие и пространство. Альтернативная человеческая география. - Лондон и Нью-Йорк, 1993.]

5. Verlaine, B. (1995). Social geography of everyday regionalization. V. 1. On ontology of society and space. Stuttgart. [in Russian]. [Верлен Б. Социальная география повседневных регионализаций. Т. 1. К онтологии общества и пространства. - Штутгарт, 1995.- C.56.]

6. Gukalova I.V. (2015). On understanding the issues of territorial identity in contemporary social geography. Ukraine's regional problems: Geographical analysis and search for solutions. Coll. of Sci. works on materials of the VI Intern. sci-pract. conference (8-9 October 2015, Kherson). Ed. I.O. Pylypenko, D.S. Malchykova. Kherson: P.P. Vyshemyrskyi, 129-135. [in Ukrainian]

[Гукалова I.В. До питання осмислення територіальної ідентичності у сучасній соціальній географії // Регіональні проблеми України: Географічний аналіз та пошук шляхів вирішення. Зб. наук. праць за матеріалами VI Міжнар. наук.-практ. конференції (8-9 жовтня 2015 р., Херсон) / За ред. І.О. Пилипенка, Д.С. Мальчикової. - Херсон: ПП Вишемирський, 2015. - С.129-135. ]

7. Karlova Ye.V. (2012). Theory and methods of territorial people community study «by self-consciousness.» Geographical sciences to ensure sustainable development strategy in the context of globalization (to 100th anniversary of Professor N.T.Romanovsky birth) Proceedings of the Intern. Sci-pract. conf., October 25-28. 2012, Minsk, Belarus / I.I. Pirozhnik (Ch. Ed.) et al. (2012). Minsk: Pub. Center of the Belarusian State University, 311-313. [in Russian].

[Карлова E.B. Теория и методика изучения территориальной общности людей «по самосознанию» // Географические науки в обеспечении стратегии устойчивого развития в условиях глобализации (к 100-летию со дня рождения профессора Н.Т. Романовского): Материалы Междунар. науч.-практ. конф., 25-28 окт. 2012 г., Минск, Беларусь / И.И. Пирожник (гл. ред.) и др. - Минск: Изд. центр БГУ, 2012. - С. 311-313.]

8. Rudenko L.H., Marunyak Eu.O., Golubtsov O.H. et al. (2014). Landscape planning in Ukraine. Ed. L.H. Rudenko. Kyiv: Discourse. [in Ukrainian].

[Ландшафтне планування в Україні / Л.Г. Руденко, Є.О. Маруняк, О.Г. Голубцов та ін.; за ред. Л.Г. Руденка. - К.: Реферат, 2014. -144 c.]

9. Lefevre A. (2010). Social space. Emergency reserves 2 (70), 3-14. [in Russian].

[Лефевр А. Социальное пространство // Неприкосновенный запас. - 2010. -№ 2 (70). - C. 3-14.]

10. Oliynyk Ya.B., Gnatiuk O.M. (2013). Methodological approaches to population territorial identity study. Ukrainian Geographical Journal, 3, 34-40. [in Ukrainian].

[Олійник Я.Б., Гнатюк О. М. Методичні підходи до дослідження територіальної ідентичності населення // Укр.геогр. журн. - 2013. - №3. - C.34-40.]

11. Pavliuk S. (2006). Sense of place and local regionalism. Homeland Notes, 5 (31), 104-113. [in Russian].

[Павлюк С. Чувство места и низовой регионализм // Отечественные записки. - 2006. - № 5 (31). - C. 104-113.]

12. Pidgrushnyi G.P., Mezentsev K.V. (2015). The attractiveness of the area for human habitat: methodological and applied aspects of research. Ukrainian Geographical Journal, 1, 32-41. [in Ukrainian].

[Підгрушний Г.П., Мезенцев К.В. Привабливість території для проживання людини: методологічні та прикладні аспекти дослідження // Укр. геогр. журн. - 2015. - №1. - С.32-41.]

13. Tennis, F. (2002). Unity and society. Basic concepts of pure sociology. St. Petersburg University Foundation Vladimir Dal. [in Russian]. $[$ Теннис, Ф. Общность и общество. Основные понятия чистой социологии. - Санкт-Петербург: Фонд «Университет», Владимир Даль, 2002. - 456 с.]

14. Freud, Z. (1989). Introduction to Psychoanalysis: Lectures. Moscow: Nauka. [in Russian].

[Фрейд, 3. Введение в психоанализ: лекции. - М. : Наука, 1989. - 456 с.]

15. Shshepanski Ya. (1969). Basic concepts of sociology. Transl. from Polish by M.M. Gurenko; Ed. and afterword. acad. A.M. Rumiantseva. Moscow: Progress. [in Russian].

[Щепаньский Я. Элементарные понятия социологии. Пер. с польск. М.М. Гуренко; под общ. ред. и послеслов. акад. А.М. Румянцева. - М.: Прогресс, 1969. - 240 с.]

16. Caldo C. (1996). Geografia Umana (Engl. Trans. Human geography). Firenze: Palumbo.

17. Pollice F. (2003). The role of territorial identity in local development processes. Proceedings of the Conference The cultural turn in geography, 18-20th of September. Gorizia Campus. Part II: Landscape Construction and Cultural Identity.

18. Proshansky H. M., Fabian,A.K., Kaminoff R. (1983). Place-identity: Physical world socialization of the self. Journal of Environmental Psychology, 3, 57-83. 